\title{
Public Relations Between the School and the Family and its Reflections on the Scientific Level of Students: A Case Study
}

\author{
Assist. Prof. Dr. Ethar Tareq Khaleel \\ Al-Iraqia University, College of Media, Iraq
}

Received: 20 May 2021; Received in revised form: 08 Jun 2021; Accepted: 20 Jun 2021; Available online: 01 Jul 2021

\begin{abstract}
The relationship between the family and the school constitutes a turning point in the scientific and cognitive level of school students, especially in the intermediate and secondary levels, as it is an important and pivotal stage in the student's life and must be followed up and coordinated between its parties in order to reach the student's scientific level, and the positive relationship between these parties will lead to the formation of a generation of students who are able to build themselves and raise their capabilities, and the most prominent results of this research are as follows:-

1- There is great agreement in support of the research sample (teachers and parents) to pay attention to the issues of academic excellence and cooperation between the family and the school.

2- There is great agreement in the lack of support of the research sample (teachers and parents) in the topics of the impact of educational lessons on educational television on the educational level and the repercussions of private educational lessons at the level of students.

3- There is great agreement and support among the research sample (teachers and parents) regarding the development of relations between the school and the family to enhance solidarity and social solidarity.

4- There is consensus not to support the existence of treating individual differences and solving emotional problems for students by the school and the family, and this indicates the weakness of the relationship and coordination between them.
\end{abstract}

The topics of observing students' behavior and discussing undesirable behaviors and phenomena practiced by some students got the support of the sample from both sides, the family and the school.

Keywords - Public relations, the family, the school and academic qualification.

\section{INTRODUCTION}

The educational process attracts the attention of the state and society all over the world because it is the best way to create an educated generation that can coexist with the developments of life. The tremendous and rapid scientific and technological progress contributes to building society and countries, and this is not only done through educational institutions, but rather needs support from the community, specifically the family through building strong relationships between the school administration and the family through parental councils. Great effectiveness in activating the educational process, but This article can be downloaded from here: www.ijaems.com

(C)2021 The Author(s). Published by Infogain Publication. because of the wars and events that took place in Iraq, it was necessary to activate the parents' councils effectively to advance the educational process. According to studies, there is a weakness in the educational process and its outputs, as well as an increase in the illiteracy rate in Iraq with the large number of students' various problems due to the openness to the outside world. The entry of modern technologies and modern means of communication such as social media is considered an additional channel in education, although it is a controversial issue because there is nothing to control its rhythms as in traditional media institutions, which required activating the role of

This work is licensed under a Creative Commons Attribution 4.0 License. http://creativecommons.org/licenses/by/4.0/ 
public relations between the school administration and the family through the activation of parents' councils to be aware of the behavior of their children.

Public relations are the link between the institution and the community that surrounds it.All institutions, including educational institutions, seek to produce a service to the community. There must be strong public relations between the institution and society for the purpose of marketing and achieving the goals that the institution seeks, in addition to the necessity of taking their opinions in evaluating these services and their endorsement and support for it, or they may have other notes. Therefore, educational institutions must strive for this relationship to be strong and continuous, so it should be based on mutual trust between the two parties.

\section{THE METHODOLOGICAL FRAMEWORK}

\subsection{Research problem and questions}

Scientific research is often based on either observing a strange phenomenon or widely spread in the community or feeling a specific problem for a specific topic or obtaining answers to questions posed by many scholars, and by using the steps of scientific research it is possible to reach answers to the questions of the problem or obtain answers to the questions raised by the scholars. What has been studied should be accurate, clear, not broad, ramified, complicated and focused.

The research problem is
an ambiguous situation
or a situation that is
suspicious, or a
phenomenon that needs
explanation, or it is an
issue about which there
have been disagreements
and differing views on it
and requires conducting
the research process in
its essence, or it is every
issue that can be realized
or observed and
surrounded by some
ambiguity, and with
attempts to simplify The
concept of the problem
and its identification, we
can say that it is an
unsatisfied need or an
obstacle to satisfying our
needs.

The research problem is an ambiguous situation or a situation that is suspicious, or a phenomenon that needs explanation, or it is an issue about which there have been disagreements and differing views on it and requires conducting the research process in its essence, or it is every issue that can be realized or observed and surrounded by some ambiguity, and with attempts to simplify The concept of the problem and its identification, we can say that it is an obstacle to satisfying our
(Al-Dulaimi, 2004, p. 33)

Through the researcher's follow-up to the literature that is concerned with social upbringing and the institutions related to it, observing educational and cultural programs through satellite channels and radio, and observing parents' councils, as well as the use of e-learning, which has become imposing itself, which adds to the functions of the family and the school, considering that digital technology affects all the cognitive, psychological, behavioral and social dynamic aspects of students.

Therefore, they have a sense of the importance of public relations in the socialization between school and the family and its reflections on students' behavior in the cognitive, affective and behavioral fields. To answer them, the most important of these questions are:

1- What is the relationship between school and family in the cognitive domain?

2- What is the relationship between school and family in the emotional field?

3- What is the relationship between the school and the family in the behavioral field?

4- To what extent did the school and the family contribute to refining the students' talent and building their personality?

5- What is the importance of the relationship between the school and the family following up on students' problems?

\subsection{The importance of research}

As a result of the great development in the field of education and the openness of students to the media and communication and its relationship in the field of social upbringing, which many educators, media professionals and researchers called to pay attention to this matter, and from this point of view emerged the importance of this research, which sheds light on an important topic at the present time, which is the importance of public relations between the school and the family and its reflections on the scientific level of the students. The importance of the research is explicit through the scientific and social importance as follows:

\subsubsection{Scientific importance:}

The importance of this research stems scientifically in dealing with an important topic, which is the knowledge of the role of public relations between the school and the family and its repercussions on the scientific level of students. In that, its importance also highlights in that it represents a knowledge addition that researchers and those in charge of preparing educational curricula, educational and media institutions benefit from. 


\subsubsection{Social importance:}

The importance of research in the social field is to identify the strengths when the school-family relationship is done through parental councils or public relations in building social cohesion for the family and society, and to shed light on the weaknesses in the weak relationship between the school and the family, as well as benefiting from the current research community institutions civilians concerned with society and the family.

\section{RESEARCH OBJECTIVES}

The current research aims to reach the following goals:

1- To reveal the relationship between the school and the family in the field of knowledge.

2- Identifying the relationship ratios between school and family in the emotional field.

3- Access to the relationship ratios between the school and the family in the behavioral field.

4- Recognizing the contribution of the school and the family in refining the talent of the students and building their personality.

5- Revealing the importance of the importance of the relationship between school and school in following up on students' problems.

\section{LIMITATIONS OF THE STUDY}

Spatial boundaries: teachers and parents of students in the city of Baghdad in both Rusafa and Karkh districts.

Time limits: The questionnaire was distributed in the period from $1 / 9 / 2020$ to 20/9/2020. This period represents the period of distributing the questionnaire to the research sample.

\section{RESEARCH METHODOLOGY}

This research is a descriptive research, and it deals with an educational media issue related to public relations between the school and the family and its reflections on the scientific level for students.The description is one of the most appropriate and best types of research to deal with such topics.

$$
\begin{aligned}
& \text { It is based on monitoring } \\
& \text { and accurate follow-up } \\
& \text { of a particular } \\
& \text { phenomenon or event in } \\
& \text { a quantitative or } \\
& \text { qualitative manner in a } \\
& \text { certain period in order to }
\end{aligned}
$$

identify the phenomenon

or event in terms of

content, in order to build

results and

generalizations that help

understand reality and

development.

(Mustafa and Mohammed, 2000, p.43)

The survey method has been used, which gives sound responses to the objectives of the current research.

The survey method is
one of the types of
approaches associated
with descriptive
research, which is the
approach that is defined
as the best method or
method for collecting
information from its
primary sources, and
presenting this data in a
form that can be used,
whether in building a
knowledge base. or the
achievement of the
study's hypotheses or
questions.

(Abdel Hameed,2000, p.13)

\section{PREVIOUS STUDIES}

\subsection{The study of Alawiyeh Al-Bukhari (2009)}

The study aimed to identify the role of parent-teacher councils in improving the school environment in the secondary stage - a field study. The study community consisted of all teachers and parents who participate as members of the 285 parent-teacher councils distributed over fifty-one schools. The researcher used the survey method to reach results that serve the objectives of the study. However, according to Al-Bukhari (2009), these councils play a vital role as the following:

1 - The work of the parent-teacher councils lies in improving and developing the school environment

2 - The educational curricula do not pay much attention to highlighting the role of parent-teacher councils in improving the school environment

3- The Ministry of Education trains members of the parent-teacher councils to contribute to self-efforts and trains them to study negative phenomena in the educational process 
4- Some parents are not obligated to attend the meeting due to circumstances or they may fear that the school burdens them with financially.

\subsection{The study of Ibrahim Maarouf (2014)}

The study aimed to identify the reality of the methods of communication between the family and kindergarten institutions and ways to develop them, specifically to identify the point of view of their teachers, principals and their parents. However, a descriptive approach has been used to obtain data and information about the phenomenon in question in its spatial and temporal reality, using the questionnaire in that.

In order to analyze it and understand its internal and external relations. According to Maarouf (2014) the study population included $(17,026)$ members of the research sample from principals, teachers and parents in public and private kindergartens in the governorate of Damascus. The researcher concluded the following:

1-Obstacles to educational communication related to parents of children came in the first order.

2- The most obstacle to educational communication is the environment surrounding the communicative process from the parents' point of view.

3- The kindergarten works on benefiting from the experiences and skills of those with academic qualifications.

4- The kindergarten teachers who have undergone more training courses agree on the importance of adopting standards for developing the communicative and participatory process to develop the reality of kindergarten.

5- The means used to communicate between the family and the kindergarten is not suitable for the nature of the future.

\subsection{The study of Abdullah Al-Hinai (2016)}

In his study, Al-Hinai (2016) aimed to identify the effectiveness of parents' councils at the state level in Al Dakhiliyah Governorate and the difficulties they encounter from their point of view.

The research community represented the participants in the parents' councils in the schools of Al Dakhiliyah Governorate, who numbered one hundred males and females, including school principals, teachers, social workers, and parents. A survey method has been adopted to obtain information that helps in reaching the research objectives, and the researcher reached to a very important set of results:
1- The current composition of the council is considered every two years as achieving the main objective in the first order within the scope of the council formation.

2- Forming committees from members to entrust them with some tasks, provided that their reports are submitted to the chairman of the council in the first order within the scope of the roles and tasks performed by the council.

3- The meeting is held in the governor's office continuously in the first order within the scope of the effectiveness of the council's meetings.

4- Educators' fear of council members' interference in the nature of their work in the first place in the field of difficulties encountered by parents' councils at the state level.

\subsection{The study of Abu al-Jalil and al-Mashrawi (2017)}

In their study, Abu al-Jalil and al-Mashrawi (2017) aimed to identify the role of social networking sites in enhancing communication between the school and parents, and in the first place determine the degree of use of the school's page on social media sites such as Facebook in following up on the various activities of the school from the parents' point of view. The phenomenon, its classification and analysis using a questionnaire to obtain the responses, the study population is consisted from seventy individuals, and the researcher concluded the following:

1- Following up on any new information about the school through its Facebook page, which came in first place within the axis of using Facebook to follow up on the school's activities.

2- Providing the school administration with all the necessary information about the safety and discipline of children by communicating on the school's page via Facebook and quickly within the axis of following up on children's achievement.

3- Receiving invitations to parents' council meetings by following the school's Facebook page. It came second in the axis of using Facebook to follow up on school activities.

4- Following up on the children's achievement by communicating through the school's Facebook page. It came in second place within the axis of follow-up to the achievement of children.

\subsection{The study of Beljilali Samia and Beljilali Khaira (2018)}

In their study, Samia and Khaira (2018) aimed to identify the role of the Association of Parents of Students in the Promotion of Educational Activity A field study in the district of Sidi Ali - Mostaganem and the study 
community consisted of twenty respondents from school principals and heads of associations.

The two researchers also used the descriptive studies approach to obtain information that achieves the objectives of the research. The study reached the following results:

1- The Students' Parents Association has an educational and social character within educational institutions that differs from other associations

2- Parents are summoned by the school principal through their children or through banners attached to the school door.

3- The presence of an association within the educational institution is not necessary because it causes problems and they interfere in administrative matters that have nothing to do with them.

4- The existence of similar problems within some educational institutions due to the absence of parents' responsibility and roles towards their children under the pretext of being busy with work and lack of time.

\section{THE THEORETICAL FRAMEWORK}

7.1. The first axis: the integration between the institutions of socialization and its reflections on building the cognitive capacities of students

Socialization is a process in which an individual learns knowledge, values, habits, trends and behavioral patterns through social interaction.It is also a growth process during which the individual transforms from a child who is dependent on others and is self-centered, whose life aims only to satisfy physiological needs, to an individual who understands the meaning of social responsibility and its transformation in accordance with social values and standards.

Socialization differs from a society unevenly. In addition, it does not mean gathering the members of society into one group, but rather it means that each individual acquires a distinct social personality within a certain cultural framework in the light of genetic and environmental factors.

However, the individual needs someone who takes his hand and directs him in the right and necessary direction so that he can live and interact with members of his group. Socialization is not confined to the family, but to several institutions, including the community, the school, places of worship, and the media, such as radio, television, books, magazines, and the press, which are considered among the most important social and cultural institutions and at the same time it is considered the most dangerous in the process of socializing children and young adults, with their attractive stimuli and effective influences, and the information and experiences they contain.In general, media has its means in an alluring manner that attracts the attention of readers, listeners and viewers to desirable topics, behaviors and situations, in addition to providing opportunities for entertainment, comfort and enjoyment of leisure time with useful things.

However, socialization takes place through the media or institutions.
A child who is born, is born into a family that is the first group in which the child learns his language, which is rightly called the mother's language, and his customs, traditions and values. Through this family, in the arms of the mother, the process of socialization begins, and the child becomes attached to his mother, then life progresses with him, and is attached to his father, brothers and relatives, then he becomes independent His social upbringing develops from home to society through that school and what it prepares for the child from other groups that move him forward in the stages of that upbringing.

(Boudraa,2005)

According to Al-Khatib (2002), the concept of socialization is defined as:

$$
\begin{aligned}
& \text { The process by which } \\
& \text { socially established } \\
& \text { individuals are able to } \\
& \text { curb their whims and } \\
& \text { organize them according } \\
& \text { to the requirements of } \\
& \text { society and its prevailing } \\
& \text { social system, and their } \\
& \text { behavior is contrary to } \\
& \text { the behavior of non- }
\end{aligned}
$$




$$
\begin{aligned}
& \text { socially established } \\
& \text { individuals, whose } \\
& \text { selfishness in satisfying } \\
& \text { their whims leads to } \\
& \text { harming others and the } \\
& \text { safety of society. (p.343) }
\end{aligned}
$$

Naima (2002) believes that socialization can be defined as:

$$
\begin{aligned}
& \text { The process through } \\
& \text { which the individual's } \\
& \text { own desires and motives } \\
& \text { are reconciled, and the } \\
& \text { interests of others, which } \\
& \text { is represented in the } \\
& \text { cultural construction in } \\
& \text { which the individual lives } \\
& \text { and the familiar use of } \\
& \text { common methods in } \\
& \text { society, such as keeping } \\
& \text { appointments and things } \\
& \text { necessary if the } \\
& \text { individual is to live in } \\
& \text { harmony with himself } \\
& \text { and with others in } \\
& \text { society. (p.21) }
\end{aligned}
$$

Abu Jadu (2007) thinks that the most important thing that the individual learns from social upbringing is the following:

$$
\begin{aligned}
& \text { The formation of basic } \\
& \text { moral concepts and } \\
& \text { values in the child. The } \\
& \text { family here has an } \\
& \text { important role in } \\
& \text { instilling and developing } \\
& \text { religious and moral } \\
& \text { values in our children and } \\
& \text { also in developing their } \\
& \text { social conscience. (p.217) }
\end{aligned}
$$

Haroosh (2005) believes that social upbringing can be understood through the psychoanalytic theory.

$$
\begin{aligned}
& \text { It includes the child's } \\
& \text { acquisition of the } \\
& \text { standards and behavior of } \\
& \text { his parents and through } \\
& \text { social upbringing } \\
& \text { methods such as reward } \\
& \text { and punishment, the child } \\
& \text { has an internal control or } \\
& \text { a conscience directing the } \\
& \text { behavior of the child and } \\
& \text { then the individual later, }
\end{aligned}
$$

$$
\begin{aligned}
& \text { and thus imitation is } \\
& \text { considered one of the } \\
& \text { most prominent methods } \\
& \text { of family upbringing. }
\end{aligned}
$$

The family is the first institution of social upbringing, as it is the first educational institution from which the individual receives the mother tongue, from which he acquires the tenderness and affection that constitute his personality in the future, and in which he/she acquires the values, customs and traditions of the society. The family is the main source of social upbringing. The family is a social system and an imperative necessity for the survival of the human race and the perpetuation of social existence.

Historical studies and books indicate the importance of the family in socialization since ancient historical times, until in the past the family was the main and basic institution in society and carried out various and multiple functions and tasks such as educational, economic, social as well as military tasks. But with the development of man and the social and civilizational change that has taken place and the accumulation of knowledge and cultures are considered other social institutions in the present era. However, the role of the family remains extremely important, which does not cause any doubt about the importance of the family because it is the first environment for the child.

Parents of students in the different stages of education can be the most helpful assistants for the teacher in providing assistance to the students in order to move forward in the educational upbringing. Therefore, it is necessary to establish an effective relationship between the parents and the school. This can only be done by informing the parents of the development in the student's performance and discussing them with regard to some of the problems faced by the student.Therefore, Sund (1995) refers to the educational upbringing as:

The importance of
training children in
scientific discovery for
the development of
mental processes based
on the representation of
scientific concepts and
principles in the mind in
childhood, as these
processes are represented
in observation,
classification,
measurement, description
and prediction. (p.61)

This article can be downloaded from here: $w w w . i j a e m s . c o m$ 
Nasser (1996) believes that the concepts of the family is "a social bond of a husband and wife with children or without children, or a single husband with children or a single wife with children."

Bogardus also defined the family as:

$$
\begin{aligned}
& \text { A small social group that } \\
& \text { usually consists of the } \\
& \text { father, the mother and } \\
& \text { one or more children, } \\
& \text { exchanging love, sharing } \\
& \text { responsibility, and raising } \\
& \text { children, so that they can } \\
& \text { direct and control them, } \\
& \text { so that they become } \\
& \text { people who act in a social } \\
& \text { way. }
\end{aligned}
$$

(Al-Kandari,1992)

The school is also the second educational environment entrusted by society and the authority to take over the affairs of educating students and raising them to achieve the goals approved by the community, because the upbringing of generations is the main function of the school, although the first manifestations of social upbringing begin and thrive in the family atmosphere, but it no longer accounts for alone with that upbringing in the contemporary world, as a result of the increasing growth of research and technology, which led to interest in education through schools created by society and became a basic building of its bases. Therefore, schools have been established in order to raise and educate its children, as no other social institution has the opportunities that the school possesses. Therefore, Schipman believes that the school is "a network of centers and roles played by teachers and students, where standards that determine their future roles in social life are acquired". (Asaad,1998,p.159)

Nasser and Ibrahim. (1996)Arab educators defined the school as "an institution established by the society to take care of the upbringing of young people, and it is that institution valuable to human civilization". (p.72)

In addition to the presence of an aspect of the socialization of students in the school, there is the educational interaction, which takes place between the members of the school group, and it is a vivid image of the social interaction that takes place within the framework of social life. The existing social interaction is manifested in the processes through which the members of the group relate to each other mentally and motively at the level of needs, desires, means, goals and knowledge. In this way, educational interaction is known as:

$$
\begin{aligned}
& \text { A reciprocal and } \\
& \text { continuous series of } \\
& \text { contacts between two or } \\
& \text { more human beings. The } \\
& \text { educational relationship } \\
& \text { is a normative pattern of } \\
& \text { behavior that achieves } \\
& \text { educational } \\
& \text { communication between } \\
& \text { students, teachers, } \\
& \text { curricula, administration, } \\
& \text { standards and values as } \\
& \text { components of the school } \\
& \text { system. }
\end{aligned}
$$

(Asaad,1998,p.162)

The activities and scientific games contribute to improving students' skills and help them study and learn science.

$$
\begin{aligned}
& \text { playing is one of the } \\
& \text { factors that support sound } \\
& \text { scientific upbringing, as } \\
& \text { educational games } \\
& \text { provide an opportunity to } \\
& \text { develop communication } \\
& \text { skills and interact with } \\
& \text { the surrounding } \\
& \text { environment and increase } \\
& \text { the student's ability to } \\
& \text { create expression and } \\
& \text { creativity as well as allow } \\
& \text { him to have a space of } \\
& \text { freedom for expression } \\
& \text { about himself in an } \\
& \text { acceptable and enjoyable } \\
& \text { social framework for him } \\
& \text { and those around him. }
\end{aligned}
$$

(Othman,1995,p.46)

The media is one of the most important institutions of socialization and the most powerful tools of change and authority over the members of society through their different segments, especially with directing their feelings and emotions, and giving psychological and social issues that are not directly related to the challenges facing their countries and their societies.

$$
\begin{aligned}
& \text { Where it may be an } \\
& \text { effective and powerful } \\
& \text { tool in spreading and } \\
& \text { establishing moral and } \\
& \text { ethical and humanitarian } \\
& \text { rules, or it may be a tool } \\
& \text { for demolishing the }
\end{aligned}
$$


society with all its value and moral rules.

(Fahmy,2002,p.213)

Fathy and Shafiq (1997) believe that the media present a role model for young people on the grounds that "the role model in the framework of socialization gives young people ideas, values, standards and emotions that fit all kinds of social roles in the family, profession, religion, politics and education."

Moreover, social media is also an effective and powerful tool in spreading and consolidating moral and human values and rules.

It may be a tool to destroy the building of society with all its value and moral rules, but the reality indicates a negative role for these means in sabotaging values and cultures, spreading chaos of all kinds and polluting socialization with a culture of hatred, extremism and death as they do The role of the social link between people and the deepening of social ties between them to reach the goal of their continuous development.

(Abu Maal,1990,p.21)

7.2 The second axis: the importance of public relations in strengthening the relationship between school and family

7.2.1 The third topic: research procedures and society, presentation and analysis of results

This topic deals with a presentation of the results of the field research and answers to the questions that were set to achieve the goals. Frequencies and percentage were calculated and the weighted mean and weight were adopted to arrange the approval of the research sample on the paragraphs of the three journals.
7.2.1.1 Research procedures: For the purpose of achieving the objectives of the current research and reaching sound responses, the researchers prepared a questionnaire to collect information from the respondents in the light of questions submitted via e-mail and were focused on knowledge of 1- gender 2- academic qualifications 3- years of service for the research sample (teachers and parents) 4- The role of the relationship between the school and the family and its reflections on students' behavior across the three axes of the table $(1,2$, $3,4,5,6)$.

7.2.1.2 The research community and its sample: The research community has been chosen from teachers and parents in the city of Baghdad, specifically the Karkh district, and the number of the research sample amounted to 354 of both sexes, from teachers 177 teachers and schools and from parents 177, males and females, and here it is necessary To mention that in defining the comprehensive enumeration method as the best method of data collection as it equips the researcher with complete data on all the vocabulary of the study community and here we must mention that in determining the comprehensive enumeration method it is the best method in data collection as it equips the researcher with complete data on all items of the study community.

Validity: For the purpose of verifying the validity of the research tool, the paragraphs of the tool in its initial form have been presented to a group of experts and academics in the fields of audio-visual and reading media and education, with the aim of identifying their views related to the degree of clarity of the questions they have and their relevance to the research sample in terms of scientific and linguistic, and in light of that was modified four out of a total of thirty-nine items distributed over three areas according to the table $(4,5,6)$. The questions are in their final form for the purpose of distributing them to the research sample according to tables $(1,2,3,4,5$, $6)$.

\begin{tabular}{|c|c|c|c|c|}
\hline No. & The Referees & $\begin{array}{c}\text { The } \\
\text { University }\end{array}$ & The College & The Specialty \\
\hline 1 & Prof. Dr. Saleh Ahmed Al-Fahdawi & Baghdad & Fine Arts & $\begin{array}{c}\text { Teaching methods } \\
\text { and art education }\end{array}$ \\
\hline 2 & Prof. Dr. Arsan Youssef Arsan & Al-Iraqiya & Media & Public Relations \\
\hline 3 & Prof. Dr. Hussein Ali Al-Falahi & Al-Iraqiiya & Media & Journalism \\
\hline 4 & Prof. Dr. Mohsen Abboud Kashkool & Al-Iraqiiya & Media & Journalism \\
\hline 5 & Prof. Dr. Sabah Anwar Al-Salihi & Al-Iraqiya & Media & Public Relations \\
\hline
\end{tabular}




\section{Statistical means:}

$(\mathrm{T} 1 \times 3)+(\mathrm{T} 2 \times 2)+(\mathrm{T} 3 \times 1)$

Acuteness $=$

As it represents:

R1: Repeat the first alternative.

R2: Repeat the second alternative.

R3: Repeat the third alternative.

TR: Total Repetitions.

Percentage weight: To indicate the value of each paragraph of the questionnaire and to benefit from it in interpreting the results, the percentage weight was used, which is represented by the following law:

Weighted mean

Weight percentile $=$ x 100

Max degree
Max score $=3$

First: the gender: From the observation of Table (1), it is clear that the participation rate of the research sample of teachers and parents for the gender (males and females) is somewhat similar, as well as the female type was also close, but the percentage of males in the male type was more for the sample of teachers and parents.

Where the sample of male teachers got (112) recurrences and a percentage of $(27,63 \%)$, and the sample of male parents got (100) iterations and a percentage of $(56,49)$. While the sample of teachers of the female type got (65) iterations and in a percentage $(36,72 \%)$ and the sample of parents obtained from the type of furniture more than the sample of teachers (77) recurring and with a percentage of $(43.50 \%)$.

Table.1: Shows the gender of teachers and parents

\begin{tabular}{|c|c|c|c|c|c|}
\hline \multirow{2}{*}{ No. } & \multirow{2}{*}{ The gender } & \multicolumn{2}{|c|}{ Teachers } & \multicolumn{2}{c|}{ Parents of students } \\
\cline { 3 - 6 } & & Participants & Percentage & Participants & Percentage \\
\hline 1 & Male & 112 & 63,27 & 100 & 56,49 \\
\hline 2 & Female & 65 & 36,72 & 77 & 43,50 \\
\hline 3 & Total & 177 & 99,99 & 177 & 99,99 \\
\hline
\end{tabular}

Second: Academic qualification: From the observation of Table (2), it is clear that the academic qualification of the research sample of teachers and parents for the bachelor degree was the predominant percentage of males and females, and they were close and ranked first, as the sample of teachers obtained (89) recurrences at a rate of $50.28 \%$, while the sample obtained Parents on (99) recurrence, with a percentage of $(93.55 \%)$.

While the scientific qualification for the $\mathrm{PhD}$ degree ranked second, and the research sample from teachers obtained (52) recurrences and a percentage of (29.37\%), while the research sample from parents obtained (42) recurrences and a percentage of $(23.72 \%)$, and this It is important to obtain responses that help achieve the objectives of the research, because the academic qualification gives more space for the sample to choose the answer correctly.

The scientific qualification for the master degree ranked third, and the research sample of teachers obtained (28) recurrences, with a percentage of $(15.81 \%)$. Get better responses to reach the objectives of the current research.

Table.2: Shows the levels of educational qualifications for teachers and parents

\begin{tabular}{|c|c|c|c|c|c|}
\hline \multirow{2}{*}{ No. } & \multirow{2}{*}{$\begin{array}{l}\text { The scientific } \\
\text { qualification }\end{array}$} & \multicolumn{2}{|c|}{ Teachers } & \multicolumn{2}{c|}{ Parents of students } \\
\cline { 3 - 6 } & & Participants & Percentage & Participants & Percentage \\
\hline 1 & Bachelor & 89 & 50,28 & 99 & 55,93 \\
\hline 2 & PhD & 52 & 29,37 & 42 & 23,72 \\
\hline 3 & Master & 28 & 15,81 & 36 & 20,33 \\
\hline 4 & Other & 8 & 4,51 & 0 & 0 \\
\hline 5 & Total & 177 & 99,97 & 177 & 99,98 \\
\hline
\end{tabular}


Third: Years of service for teachers: From the observation of Table (3) to follow up the years of service for the sample of teachers, it was found that the years of service (from 11-20 years) got the first order (67) repeatedly and with a percentage of $(85.37 \%)$, and this is a good percentage and helps to obtain more accurate responses, as the Years of service are important in the teachers' experience to give information that helps in reaching the research objectives properly.

The years of service (more than 20 years) ranked second (64) repeatedly and with a percentage of $(36.15 \%)$, and this matter is very important in obtaining a correct response because experience has an important role in providing researchers with useful information that helps to reach the research goals It should be noted that the years of service (from 11-20 years and more than 20 years 9) is very important to reach sound responses.

The years of service (from 6-10 years) came in the third order (25) recurringly and with a percentage of (14.12\%), and the years of service (less than five years) came in the fourth and last arrangement (21) repeatedly and with a percentage of $(11.86 \%)$.

Table.3: Shows the years of service for teachers

\begin{tabular}{|c|c|c|c|}
\hline \multirow{2}{*}{ No. } & Years of Service & \multicolumn{2}{|c|}{ Teachers } \\
\cline { 3 - 4 } & & Participants & Percentage \\
\hline 1 & From 11 - 20 years & 67 & 37,85 \\
\hline 2 & More than 20 years & 64 & 36,15 \\
\hline 3 & From 6 - 10 years & 25 & 14,12 \\
\hline 4 & Less than 5 years & 21 & 11,86 \\
\hline 5 & Total & 177 & 99,98 \\
\hline
\end{tabular}

7.3 The first domain: the relationship between the family and the school and its reflection on the students' cognitive domain

\section{First: View the teachers' responses}

From the observation of Table (4), it is clear that the paragraphs that got responses higher than the average according to the degree of severity and weight percentile, as follows:

1- Paragraphs $(11,10,8,9)$ got higher than the average in descending order, respectively.

A- Where Paragraph (11) (the majority of parents are concerned with the academic excellence of their children) ranked first with a degree of severity (2.92) and a weight percentage $(97,55)$, and this indicates that the sample of teachers has a great impression that parents have an interest in the excellence of their children, which is what motivates the school administration to cooperate with parents more.

B_ As Paragraph (10) obtained, cooperation between the family and the school enhances the learning process inside the home on the second order with a degree of severity (2.85) and a weight percentage $(95,10)$, and this indicates that the relationship between the school and the family enhances cooperation between them, which pushes the learning process for the better Inside and outside the home because there is integration in the learning process, which is what educational institutions aspire to.
C- In the same context, paragraph (8) the cultural level of the members of the parents' councils contributes to enhancing their interaction with the school administration ranked third with a degree of severity (2.71) and a percentage weight of $(90,39)$, which means that the cultural level of parents It is very important in the process of interaction and cooperation between the school and the family, and this matter pushes the process of learning and education for the better.

D- Paragraph (9) also helps educate parents' councils about school regulations and systems in relation to students' absences to address the educational level on the fourth rank with a degree of severity $(2,68)$ and weight percentage $(89,45)$, which indicates that the role of parents' councils is important in Awareness of the regulations and systems in addressing student absences to raise the scientific level, and here it must be noted that strengthening the relationship between the family and the school gives positive results towards the educational process.

2- Paragraphs (4,3, and 6), respectively, that got less than the average upwardly, as follows:

A- Paragraph (4) The relationship between the family and the school examines the effect of educational lessons in educational television on the educational level it got the last rank with a degree of severity $(1,83)$ and a weight percentage $(61,20)$ 
It is clear that the family and the school do not discuss the impact of the educational lessons on the educational level of the students, which is uncomfortable because the educational lessons help the students to advance their scientific level.

B - Paragraph (3) parents' councils discuss the repercussions of private educational lessons at the students' level got the sixteenth rank with a degree of severity (2.03) and a percentage weight of $(67,79)$. The issue needs to be addressed in private lessons, especially in Iraq.

C - Paragraph (6) parents' councils emphasize the activation of social networking sites to advance the educational level of students ranked fifteenth according to the degree of severity $(2,11)$ and weight percentile $(70,62)$, and this topic did not attract the attention of the research sample 'Teachers'. It seems that there is no interest in the role of social communication among teachers.

\section{Second: view parents' responses}

From the observation of Table (4), it is clear that the paragraphs that got responses higher than the average according to the degree of severity and weight percentile, as follows:

1- Paragraphs $(10,8,9)$ got higher than the average, in descending order, respectively.

A- Paragraph (10) cooperation between the family and the school enhances the learning process inside the home, it got the first rank with a degree of severity (2.92) and a weight percentage $(97,36)$ and this topic is important as the relationship between the family and the school is very important in promoting the learning process So it needs to be strengthened continuously and more.

B - Paragraph (8) the cultural level of the members of the parents' councils contributes to enhancing their interaction with the school administration) it ranked second with a degree of severity (2.75) and a weight percentage $(91,71)$, and this topic is also of great importance because it is the culture of parents It has an important role in understanding the student's situation and the educational process.

C - While paragraph (9) helps educate parents' councils about school regulations and systems in relation to students' absences to address the educational level) ranked third with a degree of severity (2.72) and a percentage weight of $(90,77)$. Also, this topic is because it helps to overcoming the obstacles of the educational process, as addressing students' absences contributes to raising the educational level of students.

2- Paragraphs $(4,3,6)$ got less than the average ascendingly and respectively:

The responses of the research sample 'teachers and parents' matched the three paragraphs $(4,3,6)(6)$ Parents' councils emphasize activating social networking sites to advance the educational level of students. Between the family and the school, the effect of educational lessons in educational television on the educational level in obtaining a low approval rate in terms of severity and weight percentile, and did not receive the attention of both parties.

Table.4: Shows the responses of the (research sample) teachers and parents on the cognitive domain

\begin{tabular}{|c|c|c|c|c|c|c|c|c|c|c|c|c|}
\hline \multirow[t]{2}{*}{ No. } & \multirow[t]{2}{*}{ Paragraphs } & \multicolumn{5}{|c|}{ Teachers' responses } & \multicolumn{6}{|c|}{ Parents' responses } \\
\hline & & Agree & $\begin{array}{l}\text { Agree to } \\
\text { some } \\
\text { extent }\end{array}$ & $\begin{array}{c}\text { Disagre } \\
\mathrm{e}\end{array}$ & $\begin{array}{c}\text { Percentag } \\
\text { e weight }\end{array}$ & $\begin{array}{l}\text { degree } \\
\text { of } \\
\text { severity }\end{array}$ & No. & Agree & $\begin{array}{l}\text { Agree to } \\
\text { some } \\
\text { extent }\end{array}$ & $\begin{array}{c}\text { Disagre } \\
\mathrm{e}\end{array}$ & $\begin{array}{c}\text { Percentag } \\
\text { e weight }\end{array}$ & $\begin{array}{c}\text { degre } \\
\text { e of } \\
\text { severi } \\
\text { ty }\end{array}$ \\
\hline 12 & $\begin{array}{l}\text { Parents' council } \\
\text { meetings } \\
\text { contribute to } \\
\text { raising the } \\
\text { educational level } \\
\text { of students }\end{array}$ & 82 & 80 & 15 & 79,28 & 2,37 & 13 & 90 & 70 & 17 & 80,41 & 2,41 \\
\hline 7 & $\begin{array}{l}\text { The school- } \\
\text { family } \\
\text { relationship deals } \\
\text { with the nature of } \\
\text { the subjects that } \\
\text { students struggle } \\
\text { with }\end{array}$ & 99 & 64 & 14 & 82,67 & 2,48 & 12 & 100 & 60 & 17 & 82,29 & 2,46 \\
\hline
\end{tabular}




\begin{tabular}{|c|c|c|c|c|c|c|c|c|c|c|c|c|}
\hline 16 & $\begin{array}{l}\text { Parents' councils } \\
\text { discuss the } \\
\text { repercussions of } \\
\text { private } \\
\text { educational } \\
\text { lessons on the } \\
\text { students' level }\end{array}$ & 62 & 59 & 56 & 67,79 & 2,03 & 16 & 75 & 45 & 57 & 70,07 & 2,10 \\
\hline 17 & $\begin{array}{l}\text { The relationship } \\
\text { between the } \\
\text { family and the } \\
\text { school examines } \\
\text { the effect of } \\
\text { educational } \\
\text { lessons in } \\
\text { educational } \\
\text { television on the } \\
\text { educational level }\end{array}$ & 33 & 82 & 62 & 61,20 & 1,83 & 17 & 50 & 75 & 52 & 66,29 & 1,98 \\
\hline 11 & $\begin{array}{l}\text { Parents' councils } \\
\text { examine the } \\
\text { impact of social } \\
\text { networking sites } \\
\text { on the } \\
\text { educational level } \\
\text { of students }\end{array}$ & 94 & 67 & 15 & 81,16 & 2,43 & 9 & 120 & 48 & 9 & 57,87 & 2,62 \\
\hline 15 & $\begin{array}{l}\text { Parents' councils } \\
\text { stress the } \\
\text { activation of } \\
\text { social } \\
\text { networking sites } \\
\text { to advance the } \\
\text { educational level } \\
\text { of students }\end{array}$ & 68 & 62 & 47 & 70,62 & 2,11 & 15 & 65 & 70 & 42 & 70,99 & 2,12 \\
\hline 14 & $\begin{array}{l}\text { The relationship } \\
\text { between the } \\
\text { school and the } \\
\text { family } \\
\text { contributes to the } \\
\text { development of } \\
\text { students' skills in } \\
\text { taking certain } \\
\text { situations }\end{array}$ & 97 & 25 & 55 & 74,57 & 2,23 & 5 & 120 & 52 & 5 & 32,88 & 2,64 \\
\hline 3 & $\begin{array}{l}\text { The cultural level } \\
\text { of the members } \\
\text { of the Parents } \\
\text { Council } \\
\text { contributes to } \\
\text { enhancing their } \\
\text { interaction with } \\
\text { the school } \\
\text { administration }\end{array}$ & 133 & 37 & 7 & 90,39 & 2,71 & 2 & 140 & 30 & 7 & 91,71 & 2,75 \\
\hline 4 & $\begin{array}{l}\text { Raising the } \\
\text { awareness of } \\
\text { parents' councils } \\
\text { about school } \\
\text { regulations and } \\
\text { systems }\end{array}$ & 126 & 46 & 5 & 89,45 & 2,68 & 3 & 140 & 25 & 12 & 90,77 & 2,72 \\
\hline
\end{tabular}




\begin{tabular}{|c|c|c|c|c|c|c|c|c|c|c|c|c|}
\hline & $\begin{array}{l}\text { regarding student } \\
\text { absences helps to } \\
\text { address the } \\
\text { educational level }\end{array}$ & & & & & & & & & & & \\
\hline 2 & $\begin{array}{l}\text { Collaboration } \\
\text { between the } \\
\text { family and the } \\
\text { school enhances } \\
\text { the learning } \\
\text { process at home }\end{array}$ & 130 & 42 & 5 & 95,10 & 2,85 & 1 & 130 & 40 & 7 & 97,36 & 2,92 \\
\hline 1 & $\begin{array}{l}\text { Most parents care } \\
\text { about the } \\
\text { academic } \\
\text { achievement of } \\
\text { their children }\end{array}$ & 116 & 54 & 7 & 97,55 & 2,92 & 4 & 132 & 35 & 10 & 89,64 & 2,68 \\
\hline 9 & $\begin{array}{l}\text { Parents' councils } \\
\text { contribute to } \\
\text { improving the } \\
\text { school } \\
\text { environment }\end{array}$ & 89 & 82 & 6 & 82 & 2,46 & 6 & 125 & 40 & 12 & 87,94 & 2,63 \\
\hline 10 & $\begin{array}{l}\text { The relationship } \\
\text { between the } \\
\text { school and the } \\
\text { family } \\
\text { contributes to the } \\
\text { promotion of } \\
\text { lofty principles } \\
\text { and Arab and } \\
\text { Islamic values in } \\
\text { the hearts of } \\
\text { students }\end{array}$ & 90 & 77 & 10 & 81,73 & 2,45 & 10 & 110 & 50 & 17 & 84,18 & 2,52 \\
\hline 8 & $\begin{array}{l}\text { The relationship } \\
\text { between school } \\
\text { and family helps } \\
\text { to overcome the } \\
\text { problem of } \\
\text { suspension of } \\
\text { studies due to the } \\
\text { Corona virus } \\
\text { crisis and } \\
\text { demonstrations }\end{array}$ & 97 & 65 & 15 & 82,10 & 2,46 & 8 & 124 & 40 & 13 & 87,57 & 2,62 \\
\hline 13 & $\begin{array}{l}\text { Activating the } \\
\text { relationship } \\
\text { between the } \\
\text { school and the } \\
\text { family, which } \\
\text { helped in the } \\
\text { establishment of } \\
\text { electronic classes } \\
\text { to maintain the } \\
\text { relationship } \\
\text { between the } \\
\text { students' } \\
\text { interaction with } \\
\text { the school }\end{array}$ & 80 & 63 & 34 & 75,32 & 2,25 & 14 & 87 & 55 & 35 & 76,45 & 2,29 \\
\hline
\end{tabular}




\begin{tabular}{|c|c|c|c|c|c|c|c|c|c|c|c|c|}
\hline 5 & $\begin{array}{l}\text { The relationship } \\
\text { between school } \\
\text { and family } \\
\text { contributes to } \\
\text { addressing the } \\
\text { poor academic } \\
\text { achievement of } \\
\text { some students }\end{array}$ & 114 & 59 & 4 & 87,38 & 2,62 & 7 & 117 & 55 & 5 & 87,75 & 2,63 \\
\hline 6 & $\begin{array}{l}\text { School and } \\
\text { family } \\
\text { interaction helps } \\
\text { address } \\
\text { individual } \\
\text { differences in } \\
\text { learning and } \\
\text { teaching }\end{array}$ & 102 & 61 & 14 & 83,23 & 2,49 & 11 & 103 & 60 & 14 & 83,42 & 2,50 \\
\hline $\begin{array}{l}\text { the } \\
\text { aver } \\
\text { age }\end{array}$ & & & & & 83 & 2,49 & & $\begin{array}{l}\text { the } \\
\text { averag } \\
\mathrm{e}\end{array}$ & & & 85,33 & 2,56 \\
\hline
\end{tabular}

7.4 The second domain: the relationship between the family and the school and its reflection on the emotional field of the students

\section{First: View teachers' responses}

From the observation of Table (5), it is clear the paragraphs that got responses higher than the average according to the degree of severity and weight percentile, as follows:

1- Paragraphs $(2,11,12)$ got higher than the average, in descending order, respectively.

A- Paragraph (2) school and family interaction helps encourage students to learn occurred according to the degree of intensity (2.74) and the weight percentile $(91,52)$. The school greatly contributes to the reform of the educational process.

B - Paragraph (11) educational awareness of parents contributes to the development of sound attitudes among students based on the degree of severity $(2,64)$ and weight percentile $(88,13)$. Their work for the better, which is reflected positively on the educational process.

C - In the same context, paragraph (12) the development of relations between the school and the family contributes to strengthening solidarity and social solidarity was scored according to the degree of severity (2.50) and the weight percentile $(83,42)$, and this indicates that public relations between the school and the family play an important role In promoting social solidarity and solidarity to build a better society, which is reflected in the building of the state.
2- Paragraphs $(5,7,1)$ got less than the average upwards, and respectively:

A- Paragraph (5) (the relationship between school and the family contributes to solving emotional problems among students) according to the degree of severity (2.07) and weight percentile $(69,11)$, which is the lowest order, and this indicates that the relationship between school and family has a weak effect in solving Emotional problems among students This is due to the students' retention of the idiosyncrasies of emotional aspects.

B - Paragraph (7) (the relationship between school and family contributes to addressing social level differences among students) according to the degree of severity $(2,18)$ and weight percentile $(72,69)$, which is the second before the last, and this indicates that the relationship between the school and the family plays a role Weak in addressing the differences in the social level of students, and this weakens in building a better society.

C - Paragraph (1) also occurred (Parents' councils play a major role in building the student's personality) according to the degree of severity $(2,22)$ and the percentage weight (74), and this indicates that the parents' councils play a weak role in building the student's personality, and this matter weakens the process of education.

\section{Second: View parents' responses}

From the observation of Table (5), it is clear that the paragraphs that got responses higher than the average according to the degree of severity and weight percentile, as follows: 
1- Paragraphs $(2,12,6)$ got higher than the average, in descending order, respectively.

A- Paragraph (2) (school and family interaction helps encourage students towards learning) occurred according to the degree of severity $(2,71)$ and the percentage weight $(58,90)$, which is the first order, and this response by parents matches the responses of the teachers completely, and this reinforces Activating the educational process to achieve better learning.

B - Paragraph (12) also occurred (the development of relations between the school and the family contributes to strengthening solidarity and social solidarity) according to the degree of severity $(2,69)$ and weight percentile (90) in the second order. This also corresponds to some extent with the teachers' responses, which is encouraging in The role of public relations to enhance solidarity and social solidarity.

C - Paragraph (6) (the unwillingness of some students to go to school is discussed in the parents' councils) according to the degree of severity $(2,61)$ and weight percentile (87) came in the third position, and this topic is important in addressing the problem of some students in the lack of Their desire to go to school and understand the problems facing students to reach effective solutions that contribute to overcoming the problems of the educational process.
2- Paragraphs $(7,5,9)$ got less than the average ascendingly and respectively:

A- Paragraph (7) (the relationship between school and family contributes to addressing social level differences among students) according to the degree of severity $(2,19)$ and weight percentile $(73,25)$ and came in the first ascending order, and this response corresponds to the response of teachers to some extent This issue needs to be addressed by the school administration and parents to address the differences in the social level to achieve social cohesion.

B - Paragraph (5) (the relationship between school and family contributes to solving emotional problems among students) according to the degree of severity $(2,30)$ and weight percentile $(76,64)$, and this result also coincides with the teachers' responses to some extent, and this topic also It needs reconsideration by the school and family administration in the Parents' Councils to contribute to addressing students' emotional problems.

C- Paragraph (9) occurred (the relationship between parents and the school contributes to refining the students' talent and nurturing them) based on the degree of severity $(2,37)$ and the weight percentage $(79,28)$. Activating the relationship between them needs to reach understandings in refining the talent of the students and nurturing them.

Table.5: Shows the responses of the (research sample) teachers and parents on the emotional domain

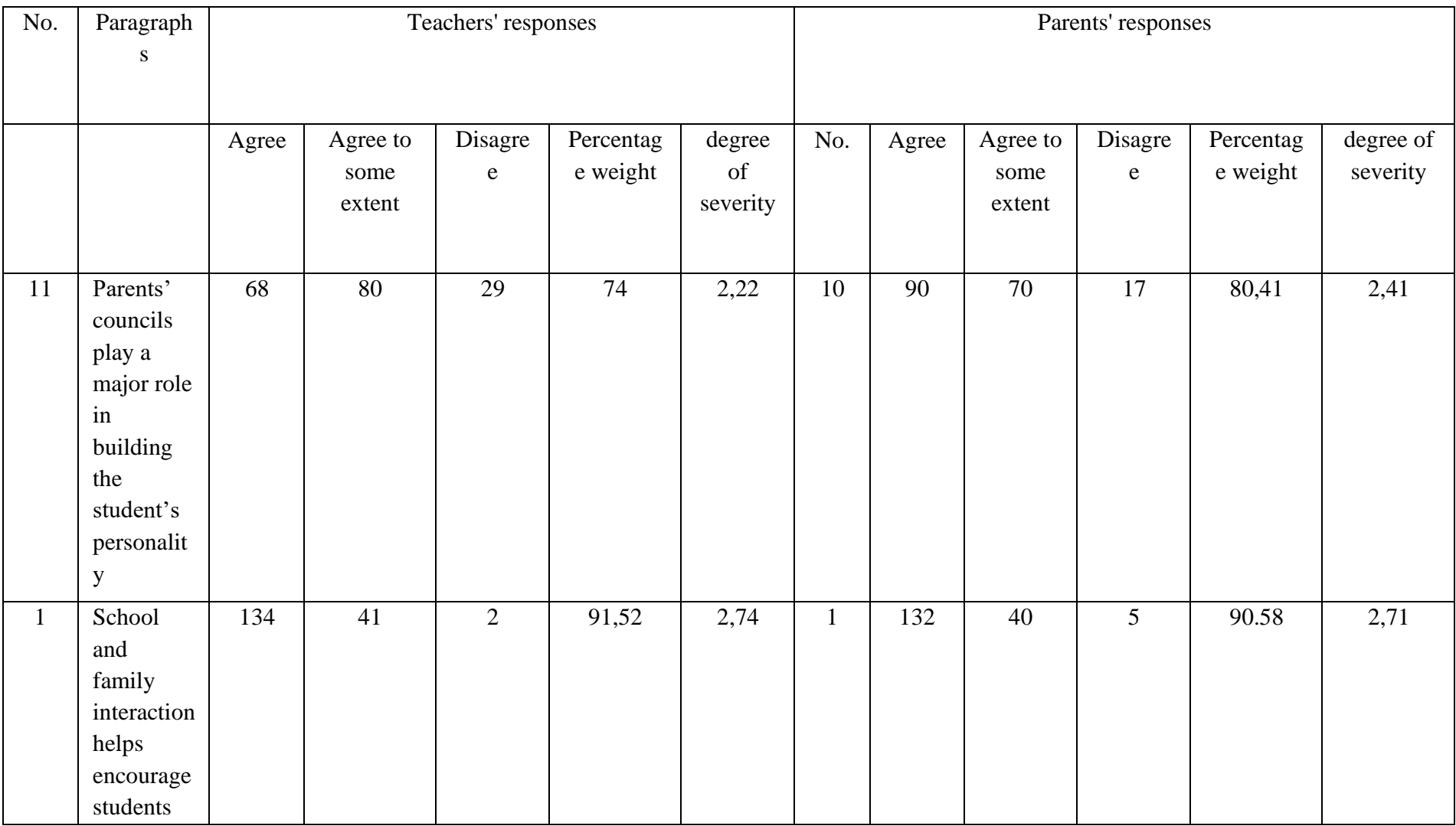




\begin{tabular}{|c|c|c|c|c|c|c|c|c|c|c|c|c|}
\hline & to learn & & & & & & & & & & & \\
\hline 10 & $\begin{array}{l}\text { The } \\
\text { relationshi } \\
\text { p between } \\
\text { school } \\
\text { and } \\
\text { family } \\
\text { contribute } \\
\text { s to } \\
\text { removing } \\
\text { the fear of } \\
\text { parents } \\
\text { bearing } \\
\text { financial } \\
\text { burdens }\end{array}$ & 63 & 92 & 22 & 38,74 & 2,23 & 8 & 95 & 70 & 12 & 82,29 & 2,46 \\
\hline 4 & $\begin{array}{l}\text { The } \\
\text { relationshi } \\
\mathrm{p} \text { between } \\
\text { school } \\
\text { and } \\
\text { family } \\
\text { contribute } \\
\text { s to } \\
\text { raising the } \\
\text { state of } \\
\text { fear } \\
\text { among } \\
\text { some } \\
\text { parents of } \\
\text { the low } \\
\text { level of } \\
\text { education } \\
\text { of their } \\
\text { children }\end{array}$ & 91 & 76 & 10 & 81,92 & 2,45 & 5 & 104 & 65 & 8 & 84,74 & 2,54 \\
\hline 13 & $\begin{array}{l}\text { The } \\
\text { relationshi } \\
\text { p between } \\
\text { school } \\
\text { and } \\
\text { family } \\
\text { contribute } \\
\text { s to } \\
\text { solving } \\
\text { emotional } \\
\text { problems } \\
\text { of } \\
\text { students }\end{array}$ & 59 & 72 & 46 & 69,11 & 2,07 & 12 & 85 & 60 & 32 & 76,64 & 2,30 \\
\hline 6 & $\begin{array}{l}\text { The } \\
\text { unwilling } \\
\text { ness of } \\
\text { some } \\
\text { students } \\
\text { to go to } \\
\text { school is } \\
\text { discussed } \\
\text { in the } \\
\text { parents' }\end{array}$ & 97 & 58 & 22 & 80,79 & 2,42 & 3 & 120 & 45 & 12 & 87 & 2,61 \\
\hline
\end{tabular}




\begin{tabular}{|c|c|c|c|c|c|c|c|c|c|c|c|c|}
\hline & councils & & & & & & & & & & & \\
\hline 12 & $\begin{array}{l}\text { The } \\
\text { relationshi } \\
\mathrm{p} \text { between } \\
\text { school } \\
\text { and } \\
\text { family } \\
\text { contribute } \\
\text { s to } \\
\text { addressing } \\
\text { social } \\
\text { level } \\
\text { difference } \\
\text { s between } \\
\text { students }\end{array}$ & 64 & 81 & 32 & 72,69 & 2,18 & 13 & 75 & 62 & 40 & 73,25 & 2,19 \\
\hline 9 & $\begin{array}{l}\text { Parents' } \\
\text { councils } \\
\text { contribute } \\
\text { to solving } \\
\text { most of } \\
\text { the } \\
\text { obstacles } \\
\text { facing } \\
\text { students }\end{array}$ & 67 & 93 & 17 & 76,08 & 2,28 & 4 & 100 & 60 & 17 & 62,86 & 2,60 \\
\hline 8 & $\begin{array}{l}\text { The } \\
\text { relationshi } \\
\text { p between } \\
\text { parents } \\
\text { and the } \\
\text { school } \\
\text { contribute } \\
\text { s to } \\
\text { refining } \\
\text { the talent } \\
\text { and care } \\
\text { of } \\
\text { students }\end{array}$ & 76 & 80 & 21 & 77 & 2,31 & 11 & 87 & 70 & 20 & 79,28 & 2,37 \\
\hline 7 & $\begin{array}{l}\text { The } \\
\text { relationshi } \\
\mathrm{p} \text { between } \\
\text { the school } \\
\text { and the } \\
\text { family } \\
\text { contribute } \\
\text { s to } \\
\text { improving } \\
\text { the } \\
\text { outward } \\
\text { appearanc } \\
\text { e of the } \\
\text { students }\end{array}$ & 89 & 68 & 20 & 79,66 & 2,38 & 9 & 100 & 50 & 27 & 80,41 & 2,41 \\
\hline 2 & $\begin{array}{l}\text { The } \\
\text { education } \\
\text { al } \\
\text { awareness } \\
\text { of parents }\end{array}$ & 122 & 47 & 8 & 88,13 & 2,64 & 7 & 100 & 68 & 9 & 83,80 & 2,51 \\
\hline
\end{tabular}




\begin{tabular}{|c|c|c|c|c|c|c|c|c|c|c|c|c|}
\hline & $\begin{array}{l}\text { contribute } \\
\mathrm{s} \text { to the } \\
\text { developm } \\
\text { ent of } \\
\text { sound } \\
\text { attitudes } \\
\text { among } \\
\text { students }\end{array}$ & & & & & & & & & & & \\
\hline 3 & $\begin{array}{l}\text { The } \\
\text { developm } \\
\text { ent of } \\
\text { relations } \\
\text { between } \\
\text { the school } \\
\text { and the } \\
\text { family } \\
\text { contribute } \\
\text { s to the } \\
\text { strengthen } \\
\text { ing of } \\
\text { solidarity } \\
\text { and social } \\
\text { solidarity }\end{array}$ & 99 & 68 & 10 & 83,42 & 2,50 & 2 & 110 & 50 & 17 & 90 & 2,69 \\
\hline 5 & $\begin{array}{l}\text { The } \\
\text { relationshi } \\
\text { p between } \\
\text { the school } \\
\text { and the } \\
\text { family } \\
\text { works to } \\
\text { follow up } \\
\text { on what is } \\
\text { issued by } \\
\text { the } \\
\text { meetings } \\
\text { of the } \\
\text { parents' } \\
\text { councils }\end{array}$ & 92 & 73 & 12 & 81,73 & 2,45 & 6 & 100 & 70 & 7 & 84,18 & 2,52 \\
\hline $\begin{array}{l}\text { the } \\
\text { aver } \\
\text { age }\end{array}$ & & & & & 79 & 2,37 & & $\begin{array}{c}\text { the } \\
\text { averag } \\
\text { e }\end{array}$ & & & 82,66 & 2,48 \\
\hline
\end{tabular}

7.5 The third domain: the relationship between the family and the school and its reflection, the behavioral domain of students

\section{First: View the teachers' responses}

From the observation of Table (6), it is clear that the paragraphs that got responses higher than the average according to the degree of severity and weight percentile, as follows:
1- Paragraphs (2, 7 and 8) got higher than the average in descending and successive manner.

A - Paragraph (2) occurred: "Parents' councils call on parents to be aware of observing the behavior of their children in the first order according to the degree of severity (2.76) and weight percentile $(92,27)$, and this topic is very important because the behavior is the result of the cognitive and emotional field of students, and the behavior of students gives impressions and has many indications. 
B - Paragraph (7) Parents' meetings follow up on students' behavior) ranked second based on the degree of severity $(2,69)$ and weight percentile $(89,83)$. This matter is also of great importance in activating the educational process and controlling it in a way that achieves desired learning.

C- In the same context, Paragraph (8) Parents' councils contribute to discussing the undesirable behaviors and phenomena practiced by some students ranked third according to the degree of severity $(2,67)$ and weight percentile $(89,26)$ where there are undesirable phenomena that appear on the behavior of students, it needs emergency sessions for parents' councils to reduce it before it escalates.

2- Paragraphs $(5,3,1)$ that got less than the average in descending order and as follows.

A- Paragraph (5) strengthening the relationship between the school and the family by motivating parents' councils for school visits and various artistic and cultural exhibitions ranked the last according to the degree of severity $(2,21)$ and weight percentile $(73,82)$ and did not receive the support of the sample of teachers, which is reflected Negatively on the educational process, because informing parents about cultural activities and exhibitions enhances trust between the school and the family and motivates parents to communicate with the school better.

B - Paragraph (3) the relationship between the family and the school works to form joint committees to solve students' problems ranked second before the last according to the degree of severity $(2,40)$ and the weight percentile $(80,22)$, as the joint committees between the school and parents It enhances communication and communication between them and helps activate the educational process.

C - Paragraph (1) targeting the relationship between school and family in addressing the poor contribution of parents' councils in school activity) ranked third before last according to the degree of severity $(2,41)$ and weight percentile $(80,60)$ and this topic did not receive attention Teachers sample where participation in internal school activities is very important in strengthening the relationship between the family and the school and motivates students to take an interest in following up on the school and enhances their affiliation with it.

\section{Second: view parents' responses}

From the observation of Table (6), it is clear that the paragraphs that got responses higher than the average according to the degree of severity and weight percentile, as follows:

1- Paragraphs $(2,8,4)$ got higher than the average in descending order, respectively:
A- Paragraph (8) Parents' councils contribute to discussing undesirable behaviors and phenomena practiced by some students ranked first according to the degree of severity (2.76) and weight percentile $(92,27)$, and this response corresponds to some extent with the teachers' responses, which is there is reason for optimism in dealing with improper behaviors and phenomena in order to preserve the students and the educational process.

B - Paragraph (2) parents' councils call on parents to be aware of observing the behavior of their children ranked second according to the degree of severity $(2,75)$ and weight percentile $(91,71)$.

This response also coincides with the school's response to a large extent, which is important in controlling students' behavior to build a healthy society.

C- Paragraph (4) Parents' councils contribute to the development of the communication process between the school and the family in all its forms and types ranked third according to the degree of severity $(2,66)$ and weight percentile $(88,88)$ and this topic was supported by a sample of parents More than teachers, and there seems to be a desire among parents to activate parents' councils to enhance the process of communication between the school and the family.

2- Paragraphs $(1,3,9)$ got lower than the average in an ascending manner, and respectively:

A- Paragraph (1) targeting the relationship between the school and the family in addressing the weak contribution of parents' councils in school activity ranked last according to the degree of severity $(2,37)$ and weight percentile $(79,28)$, and this corresponds to the teachers' response regarding the topic of contribution Parents' councils in school activities, and there seem to be more important issues for parents.

B - Paragraph (3) the relationship between the family and the school works to form joint committees to solve students' problems was ranked penultimately according to the degree of severity $(2,44)$ and weight percentile $(81,35)$, and this completely coincides with the teachers' response and it seems that there is no Joint committees or may be very weak.

C- Paragraph (9) Parents' councils work to contribute to improving the school environment and its development ranked third before the last based on the degree of severity $(2,53)$ and weight percentile $(84,55)$ and this topic did not attract the attention of parents and even teachers despite its importance, which calls for activating this in the future, as improving and developing the school environment contributes to revitalizing the educational process and helps attract students to the school. 
Table.6: Shows the responses of the (research sample) teachers and parents to the behavioral domain

\begin{tabular}{|c|c|c|c|c|c|c|c|c|c|c|c|c|}
\hline $\mathrm{N}$ & Paragraphs & & & chers' res & onses & & & & Par & its' respo & & \\
\hline & & Agree & $\begin{array}{c}\text { Agree to } \\
\text { some } \\
\text { extent }\end{array}$ & $\begin{array}{c}\text { Disagre } \\
\text { e }\end{array}$ & $\begin{array}{c}\text { Percentag } \\
\text { e weight }\end{array}$ & $\begin{array}{c}\text { degree } \\
\text { of } \\
\text { severity }\end{array}$ & No. & Agree & $\begin{array}{c}\text { Agree } \\
\text { to some } \\
\text { extent }\end{array}$ & $\begin{array}{c}\text { Disagre } \\
\mathrm{e}\end{array}$ & $\begin{array}{c}\text { Percentag } \\
\text { e weight }\end{array}$ & $\begin{array}{c}\text { degree of } \\
\text { severity }\end{array}$ \\
\hline 1 & $\begin{array}{l}\text { School and } \\
\text { family } \\
\text { interaction } \\
\text { helps } \\
\text { encourage } \\
\text { students to } \\
\text { learn }\end{array}$ & 139 & 35 & 3 & 92,27 & 2,76 & 2 & 138 & 34 & 5 & 91,71 & 2,75 \\
\hline 8 & $\begin{array}{l}\text { The } \\
\text { relationship } \\
\text { between } \\
\text { school and } \\
\text { family } \\
\text { contributes to } \\
\text { removing the } \\
\text { fear of } \\
\text { parents } \\
\text { bearing } \\
\text { financial } \\
\text { burdens }\end{array}$ & 90 & 69 & 18 & 80,22 & 2,40 & 8 & 95 & 65 & 17 & 81,35 & 2,44 \\
\hline 9 & $\begin{array}{l}\text { The } \\
\text { relationship } \\
\text { between } \\
\text { school and } \\
\text { family } \\
\text { contributes to } \\
\text { solving } \\
\text { emotional } \\
\text { problems of }\end{array}$ & 65 & 85 & 27 & 73,82 & 2,21 & 4 & 97 & 60 & 20 & 88,70 & 2,66 \\
\hline
\end{tabular}




\begin{tabular}{|c|c|c|c|c|c|c|c|c|c|c|c|c|}
\hline & students & & & & & & & & & & & \\
\hline 6 & $\begin{array}{l}\text { The } \\
\text { unwillingness } \\
\text { of some } \\
\text { students to go } \\
\text { to school is } \\
\text { discussed in } \\
\text { the parents' } \\
\text { councils }\end{array}$ & 94 & 65 & 18 & 80,97 & 2,42 & 5 & 120 & 49 & 8 & 87,75 & 2,63 \\
\hline 2 & $\begin{array}{l}\text { The } \\
\text { relationship } \\
\text { between } \\
\text { school and } \\
\text { family } \\
\text { contributes to } \\
\text { addressing } \\
\text { social level } \\
\text { differences } \\
\text { between } \\
\text { students }\end{array}$ & 127 & 43 & 7 & 89,83 & 2,69 & 6 & 110 & 62 & 5 & 86,44 & 2,59 \\
\hline 3 & $\begin{array}{l}\text { Parents' } \\
\text { councils } \\
\text { contribute to } \\
\text { solving most } \\
\text { of the } \\
\text { obstacles } \\
\text { facing } \\
\text { students }\end{array}$ & 126 & 45 & 6 & 89,26 & 2,67 & 1 & 140 & 33 & 4 & 92,27 & 2,76 \\
\hline the & iverage & & & & 83,33 & 2,50 & & $\begin{array}{l}\text { the } \\
\text { averag } \\
\text { e }\end{array}$ & & & 86,33 & 2,37 \\
\hline
\end{tabular}

\section{CONCLUSION}

In light of the results of the responses of the research sample (teachers and parents) to the three areas which are the cognitive domain, the emotional domain and the behavioral domain. Therefore, it has been concluded the following:

\section{1- Cognitive domain}

A- There is a great consensus in support of the research sample (teachers and parents) to pay attention to the issues of academic excellence and cooperation between the family and the school and to pay attention to the cultural level of members of the parents' councils to enhance and raise awareness of school regulations and systems to advance the educational level, which is important for the advancement of the educational process.

B- There was also a great agreement in the lack of support of the research sample (teachers and parents) in the topics of the impact of educational lessons on educational television on the educational level and the repercussions of private educational lessons at the level of students and the activation of social networking sites to advance the

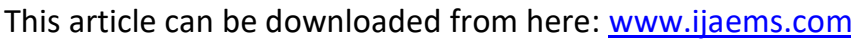


educational process. This matter needs attention as educational television is an important aiding factor for students in the educational process, as well as discussing private lessons that constitute a burden on parents and weaken the educational process, as well as rationalizing the follow-up of social networking sites to serve the educational process.

\section{2- Emotional domain}

A- There is great agreement and support among the research sample (teachers and parents) regarding the development of relations between the school and the family to enhance solidarity and social solidarity and encourage students towards learning.

B- There is also agreement not to support the existence of treating individual differences and solving emotional problems for students by the school and the family, and this indicates the weakness of the relationship and coordination between them, which requires activating the relationship in the parents' councils to overcome the problems facing the students.

3- Behavioral domain

A- The topics of observing students' behavior and discussing undesirable behaviors and phenomena practiced by some students got the support of both sides of the sample, especially at a time when we are witnessing undesirable behaviors and phenomena, so attention needs to be paid to them always to build a healthy society.

B- As for the issues of forming joint committees to solve students' problems and address the weak contribution of parents' councils in school activity, their support was weak among the research sample on both sides, which requires preparing joint committees and making field visits to revitalize the educational process.

\section{REFERENCES}

[1] Abdel Hamid, H. (2021). Scientific Research in Media Studies (p. 13)(K. Ethar, Trans.). Cairo: World of Books. (2000)

[2] Abu Al-Hail, K., \& Al-Masharawi, A. (2021). The Role of Social Media in Enhancing Communication between School and Parents(K. Ethar, Trans.). State of Palestine, Gaza: Research Project on Spreading the Culture of Scientific Research. (2017)

[3] Abu Jadu, S. (2021). Psychology of Socialization (p.217) (K. Ethar, Trans.). Amman:Dar Al Masirah for Publishing and Distribution. (2007)

[4] Abu Maal, A. (2021). The Impact of the Media on the Child(K. Ethar, Trans.). Amman: Dar Al-Shorouk. (1990)

[5] Al-Bukhari, A. (2021). The Role of Parents and Teachers Councils in Improving the School Environment in the
Secondary Stage (Master thesis)(K. Ethar, Trans.). Omdurman Islamic University. (2009)

[6] Al-Dulaimi, H. J. (2021). The Basics of Systematic Research (pp. 33-34)(K. Ethar, Trans.). Baghdad: AlHadara Printing Company. (2004)

[7] Al Hinai, A. (2021), the effectiveness of fathers' and mothers' councils at the state level in Al Dakhiliyah Governorate and the difficulties they encounter from their point of view(Master thesis)(K. Ethar, Trans.). University of Nizwa. (2016)

[8] Al-Kandari, M. (2021). Family Psychology.(K. Ethar, Trans.).Kuwait : Al Falah Library for Publishing and Distribution. (1992)

[9] Al-Khatib, S. A. (2021).Contemporary look at contemporary sociology (p.343) (K. Ethar, Trans.). Cairo: Nile Press for printing, publishing and distribution. (2002)

[10] Asaad, W. (2021). Educational Sociology and Contemporary Educational Life Issues, 2nd Edition (K. Ethar, Trans.).Kuwait: Al Falah Library for Publishing and Distribution. (1998)

[11] Boudraa, A. (2021).The relationship of family and socialization to school violence(Master Thesis) (K. Ethar, Trans.), Faculty of Social Sciences and Humanities, Department of Sociology, Hadj Lakhdar University, Batna. (2004)

[12] Fahmy, M. (2021). Introduction to Social Service(K. Ethar, Trans.). Alexandria: Modern University Office. (2002)

[13] Fathy, M. and Shafiq, M.(2021). Introduction to Social Psychology(K. Ethar, Trans.). Alexandria: Al-Hadith. (1997)

[14] Haroosh, R. (2021).Methods of family upbringing and its implications for the adolescent (Master Thesis)(K. Ethar, Trans.). Department of Sociology. Batna. (2005)

[15] Maarouf, I. (2021). The Reality of Communication Methods between the Family and Kindergarten Institutions in the Light of Modern Trends and Ways to Develop them (Master thesis)(K. Ethar, Trans.). Damascus University. (2014)

[16] Mustafa, R., \& Mohammed, O. (2021). Scientific Research Methods and Methods, Theory and Application (p. 43)(K. Ethar, Trans.). Amman: Amman Dar Al-Safa Publishing and Distribution. (2000)

[17] Naima, M. M. (2021). Socialization and Personality Traits, Alexandria, Dar Al-Taqqaf Al-Scientia for Printing (p.21) (K. Ethar, Trans.), Publishing and Distribution. (2002)

[18] Nasser, I. (2021).Educational Sociology. (K. Ethar, Trans.). Beirut:Dar Al-Jeel Publishing. (1996).

[19] Othman, F. (2021).The Psychology of Play and Learning(K. Ethar, Trans.). Amman: Dar Al-Maarifa for Publishing and Distribution. (1995)

[20] Samia, B. and Khaira, B. (2021). The Role of the Parents' Association in Advancement of Educational Activity $(\mathrm{K}$. Ethar, Trans.), Graduation Research for a Master's Degree, Field Study in the Sidi Ali District - Mostaganem, Algeria. (2018)

[21] Sund, R (2021).Teaching Science by Inquiry In the secondary school(p.61) (K. Ethar, Trans.) . Ohio: Merrill press. (1995) 